\title{
Multinodular and vacuolating neuronal tumor of the cerebrum の長期経過 と文献的考察
}

\author{
山澤 恵理香 ${ }^{1)}$, 大野 誠1，里見 介史 ${ }^{2)}$, 吉田 朗彦 ${ }^{2)}$, 宮北 康二 ${ }^{1 ｝ \text { ，高橋 雅道 }{ }^{1)} \text {, }$ \\ 浅野目 卓 ${ }^{1)}$, 里見 奈都子 ${ }^{1)}$, 成田 善孝 ${ }^{1)}$ \\ 1）国立がん研究センター中央病院脳脊髄腫瘍科，2）国立がん研究センター中央病院病理科
}

\section{Longitudinal Follow ${ }^{-}$up of a Case of Multinodular and Vacuolating Neuro- nal Tumor of the Cerebrum and Review of the Literature}

\author{
Erika Yamazawa, M.D. ${ }^{1)}$, Makoto Ohno, M.D., Ph.D. ${ }^{1}$, Kaishi Satomi, M.D., Ph.D. ${ }^{2)}$, \\ Akihiko Yoshida, M.D., Ph.D. ${ }^{2)}$, Yasuji Miyakita, M.D. ${ }^{1}{ }^{\text {, }}$, Masamichi Takahashi, M.D., Ph.D. ${ }^{1)}$, \\ Taku Asanome, M.D. ${ }^{1)}$, Natsuko Satomi, M.D. ${ }^{1{ }^{\prime}}$, and Yoshitaka Narita, M.D., Ph.D. ${ }^{1{ }^{\prime}}$ \\ 1) Department of Neurosurgery and Neuro-Oncology, National Cancer Center Hospital, 2) Department of Pathology and \\ Clinical Laboratories, National Cancer Center Hospital
}

Multinodular and vacuolating neuronal tumor of the cerebrum (MVNT) is a relatively new tumor classification. There are only a few reports of long-term prognosis for MVNTs. Here we report a 5-year follow-up of our case of MVNT with no recurrence after surgery. We also summarize and discuss the literature for 31 other cases. Median age was 41 years, and there was no sex disparity. In around half of the cases, nodules were visible not only by examination of the pathological tissue but also on MRI. In most symptomatic epilepsy improves with surgery. Thus far no malignant transformation of MVNT has been reported, indicating a good prognosis.

(Received July 26, 2018; accepted August 17, 2018)

Key words : multinodular and vacuolating neuronal tumor of the cerebrum, MVNT, multinodular, MAP kinase

Jpn J Neurosurg（Tokyo）28:27-32, 2019

\section{緒 言}

Multinodular and vacuolating neuronal tumor of the cerebrum（MVNT）は 2013 年に Huse $ら^{6)}$ によって最初に提 唱された比較的新しい疾患概念である。主に成人の大脳 半球皮髄境界部に発生する空胞化異型神経細胞から構成 される多結節性病変であるが, 長期間観察された臨床経 過に関する報告は少ない. 今回われわれはMVNTの自験
例の 5 年経過を報告し文献的考察を加える.

\begin{abstract}
症 例
37 歳男性, 運動性の失語症状を呈する 1 時間程度の一 過性の言語障害で発症.MRIにて左頭頂葉に皮質に沿つ た $26 \times 17 \times 14 \mathrm{~mm}$ 大の比較的均一な病変を認めた。病変 は造影増強効果を伴わず T2 および FLAIR で高信号, T1
\end{abstract}



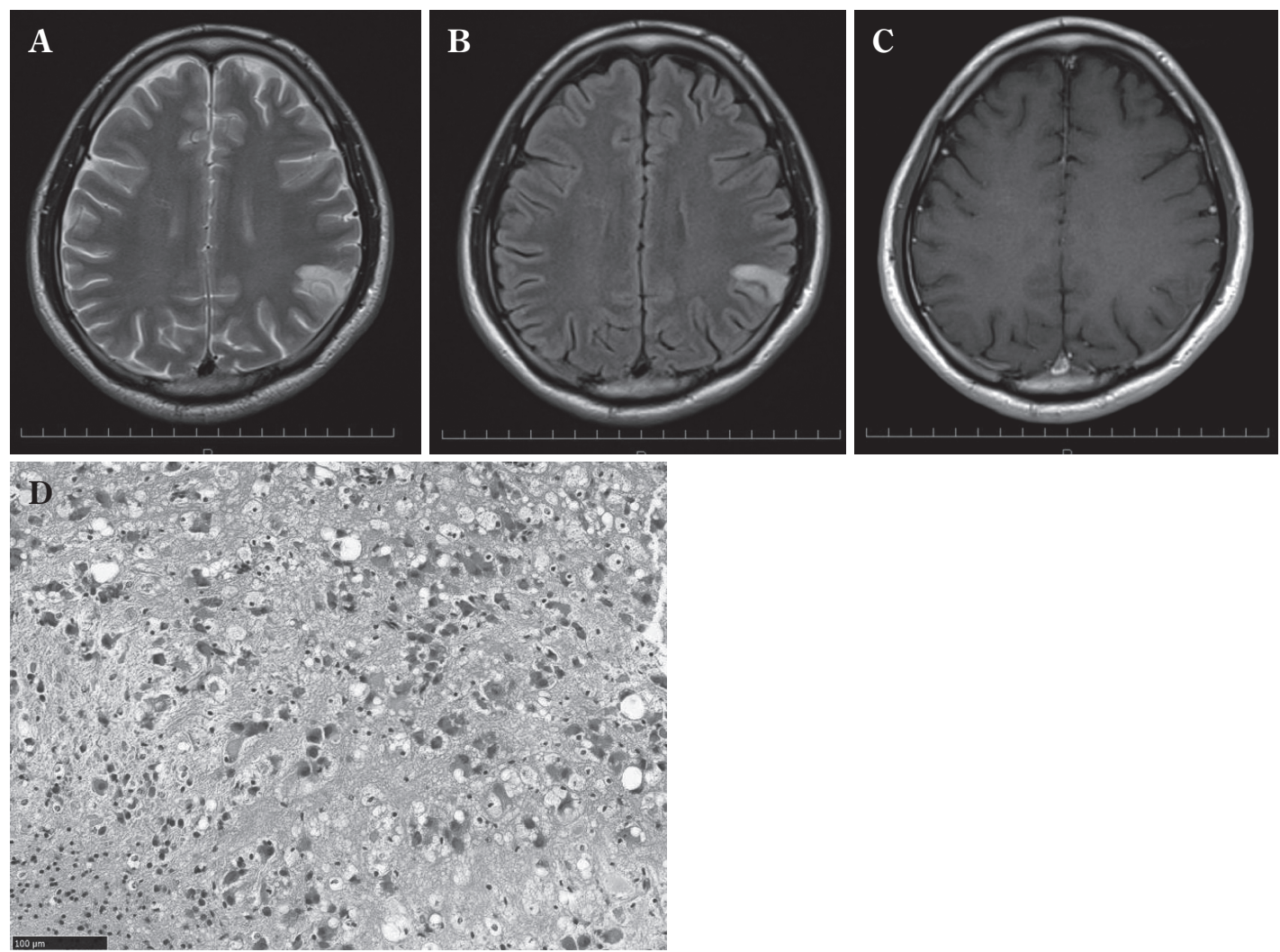

Fig. 1 Magnetic resonance images showed a solid lesion in the superficial left parietal lobe The lesion showed high intensity on $\mathrm{T} 2{ }^{-}$weighted images (A) and fluid-attenuation inversion recovery images (FLAIR) (B). The lesion was not enhanced on T1-weighted images with gadolinium diethylenetriamine pentaacetic acid (C). Histomorphology of multinodular and vacuolating neuronal tumor. The multinodular lesion comprised coarse vacuolated stroma and irregular proliferation of neuronal cells (hematoxylin and eosin stain, $\mathbf{D})$.

等信号, 拡散強調画像では軽度拡散抑制がみられた (Fig. 1). MRS で choline/ $\mathrm{N}$-acetylaspartate（NAA）比の上昇 を認め, ${ }^{11} \mathrm{C}$-methionine positron emission tomography (PET)では取り込みの増加を認めなかった。症候性てん かんの診断でバルプロ酸を投与した。術前は失語症状を 含む神経学的異常所見は認めなかった。特記すべき既往 歴や家族歴はなかった。ナビゲーションシステムを用い た覚醒下開頭腫瘍摘出術にて FLAIR 高信号域の全摘出 を行った。腫瘍は灰白色で, 5-ALA での蛍光発色は陰性 であった。術後は経過良好で, 明らかな神経学的異常所 見なく独歩にて自宅退院した。

バルプロ酸投与を終了した以後，追加の放射線治療や 化学療法は行わずに 6 力月おきの MRI フォローを行って いる. 手術後 5 年が経過しているが神経学的に異常なく, 腫瘍再発や痓攣発作は認めない (Fig. 2).

病理学的には, 深部灰白質一白質浅層に周囲灰白質を 圧排する不明瞭な結節形成を認めた。結節内では小型で 好酸性細胞質を有する異型に乏しい細胞が不規則に増殖
していた。分化傾向は不明瞭だが一部で神経細胞への分 化がみられた。細胞内および間質に空胞変性を伴ってい た. 石灰化や Rosenthal 線維をはじめとする二次性変化, 不整な神経膠細胞の増生は観察されなかった。免疫学的 染色では病変細胞に $\mathrm{HuC} / \mathrm{HuD}$, Olig2, synaptophysin が 陽性であった。 GFAP, NeuN, chromogranin A, neurofilament, p53 は陰性であった。MIB-1 陽性率は $1 \%$ 未満 であった。病変周囲に CD34 陽性の樹状分枝を示す間質 細胞が観察された。免疫染色による変異検索で病変細胞 はIDH1 R132H および BRAF V600E は陰性であった ${ }^{4)}$.

\section{文献の検索結果}

2013〜2018 年にかけて PubMed で “multinodular and vacuolating neuronal tumor” と検索したところ，19の検 索結果が認められた。そのうち，論文として出版されて おり, 病理組織学的に確定診断がついているものは 11 論文 36 例であった。そのうち各症例の経過・画像所見・ 

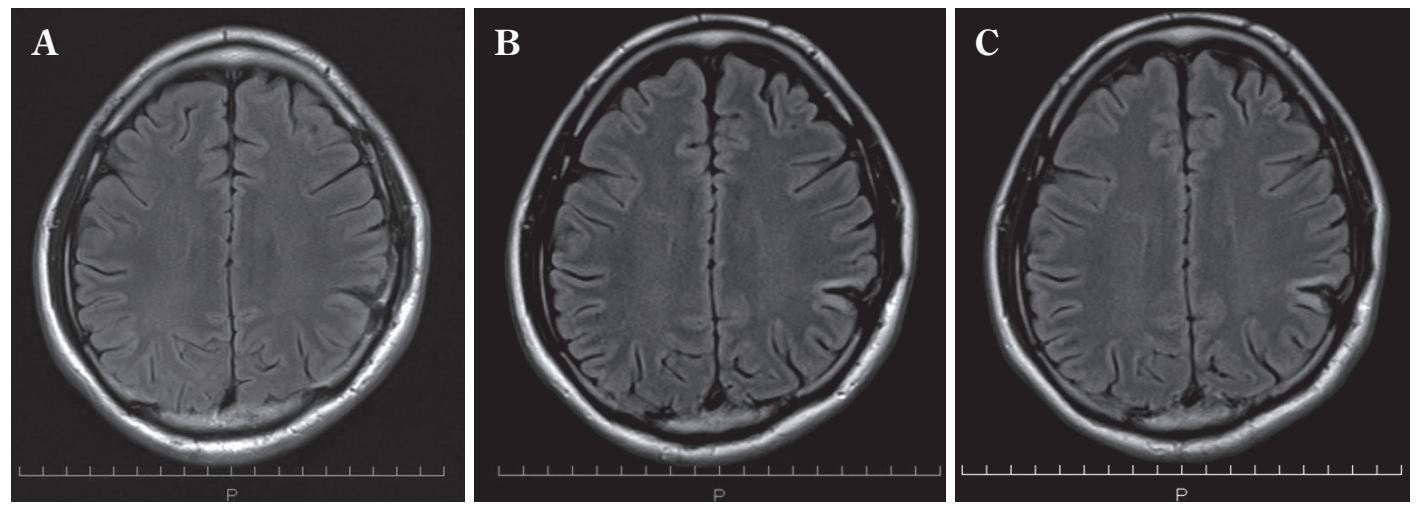

Fig. 2 Postoperative follow up images (FLAIR)

A : One month after operation

B : Two and a half years after operation

C : Five years after operation

病理診断が記載された 10 論文 32 例について Table 1 に まとめた ${ }^{2) \sim 7) 9) \sim 12) . ~}$

年齢分布は $6 \sim 71$ 歳，中央值は 41 歳であった。 女性 17 名, 男性 15 名で明らかな性差は認められなかった。 発生部位では側頭葉（扁桃体, 海馬を含む) が 25 例と最 も多く, 次いで前頭葉 4 例, 頭頂葉 3 例, 後頭葉 1 例, の結果であった（部位重複症例あり）。2 21 例 (65.6\%) の 症例でてんかん発作を合併していた。術後フォローでも てんかん発作が消失せず，明らかに残存している症例は 3 例 (9.4\%) であった. MRI では全症例でT2/FLAIR に て高信号病変を認め，造影病変を認めた症例は 2 例のみ であった。この 2 例はそれぞれ術後 16 力月と 12 力月の フォローでは病変の再発はなかった. MRS 施行例では 3 例中 3 例で choline/NAA 比の上昇を認めている. MRIで 多結節性を示すのは, Gonzalez-Quarante $ら^{5)}$ の報告で は, 約半数 16 例中 7 例 $(43.8 \%)$ であった。今回検索し た 32 例中では 15 例 $(46.9 \%)$ であった。

過去には放射線治療が行われた症例もあるが, 組織学 的に MVNT と診断されて, 術後経過観察中に再発・増大 した症例は今回調べた 32 例中では報告されていない.

\section{考 察}

MVNT は成人の大脳半球（側頭葉が最多）に発生し, しばしばてんかん発作を合併する。画像所見はCTでは, 淡い低吸収域を認めるか，もしくは明らかな異常所見が 認められないことが多い. 今回検索した 32 例中で画像 上の石灰化が報告された症例はなかった，MRIでは, 脳 表の皮質から皮質下白質にかけて T2 および FLAIR で高 信号を示し，T1 は等信号から低信号を示し，DWIでの
拡散制限は認めないことが多い，造影されることはまれ で，32 例中 2 例 $(6.3 \%)$ のみ造影の報告がある. MRI 上，多結節性の像を示すのはおよそ半数である ${ }^{5)}$.

病理組織学的には皮質深層から皮質下白質にかけて, 空胞化異型神経細胞から構成される境界明瞭な多結節病 変である，免疫組織学的所見としては神経細胞の分化段 階の早期に発現する $\mathrm{HuC} / \mathrm{HuD}$ が陽性となる。 Glia 系 マーカーの Olig2 も陽性となることが多い。一方で神経 細胞系マーカーの NeuN, neurofilament, chromogranin, glia 系マーカーの GFAP は陰性であることが多い. 腫瘍 周囲の組織に網状の CD34 陽性所見を認めることも多 い. MVNT の予後は良好で, 組織学的に MVNT と診断 されて, 術後経過観察中に再発・増大した症例は今回文 献を調べた 32 例中では報告されていない。症候性てん かんを伴う症例は病変切除がてんかんコントロールに有 効であり, 本例も術後 5 年間再発・てんかん発作を認め ない.

MRI 画像のみでMVNT と診断して経過報告をしてい る論文では Alsufayan (1) $^{1)} 24$ 例 30 病変の症例のうち 19 例 23 病変を 2 93 力月（中央值 13.7 力月）追跡して, 1 例を除いて画像変化は認められなかった。その 1 例も 3 カ月目のフォローアップで増大が認められたがその後 の 6 カ月目のフォローでは増大が停止していたと報告し

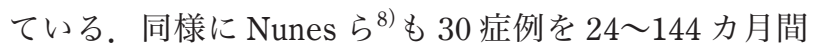
(平均 36.8 力月) フォローして $100 \%$ 画像上の変化はな かったと報告している。

MVNT の遺伝子異常については MAP kinase pathway の遺伝子変異が報告されている ${ }^{9)}$ MVNT の鑑別診断と して, dysembryoplastic neuroepithelial tumor (DNT), gangliocytoma, glioma などが挙げられるが，側頭葉のて 
Table 1 Review of the literature

Previous case reports of MVNT.

\begin{tabular}{|c|c|c|c|c|c|c|c|c|}
\hline No. & Year & Location of the tumor & $\begin{array}{c}\text { Age/ } \\
\text { Sex }\end{array}$ & Clinical presentation & Surgery & \begin{tabular}{|c|} 
Other \\
treatment
\end{tabular} & Follow-up & Ref \\
\hline 1 & 2013 & $\begin{array}{l}\text { Rt. temporal, hippocampus, } \\
\text { and para-hippocampal gyrus }\end{array}$ & $38 / \mathrm{M}$ & Dizziness/loss of attention (2 years) & SR & No & 8 months/no recurrence & (6) \\
\hline 2 & 2013 & Lt. amigdala & $54 / \mathrm{F}$ & $\begin{array}{l}\text { Dizziness/dysarthria/blurred vision/ } \\
\text { Rt. numbness ( } 1 \text { episode) }\end{array}$ & TR & Radiation & 66 months/no recurrence & (6) \\
\hline 3 & 2013 & Rt. parietal & $38 / \mathrm{F}$ & Grand mal seizure ( 1 episode) & $\begin{array}{l}\text { Biopsy } \\
\text { follow ed by } \\
\text { n e a r-t o t a } 1 \\
\text { resection }\end{array}$ & No & $\begin{array}{l}16 \text { months/no recurrence/no epilepsy } \\
\text { with AED }\end{array}$ & (6) \\
\hline 4 & 2013 & Rt. temporal & $35 / \mathrm{M}$ & Episodic confusion (14 months) & \begin{tabular}{|l|l} 
SR \\
\end{tabular} & No & 6 months/no regrowth & (6) \\
\hline 5 & 2013 & Rt. temporal & $54 / \mathrm{M}$ & $\begin{array}{l}\text { Partial complex and grand mal sei- } \\
\text { zure }(>40 \text { years })\end{array}$ & TR & No & 11 months/no recurrence & (6) \\
\hline 6 & 2013 & $\begin{array}{l}\text { Lt. temporal, and supramar- } \\
\text { ginal gyrus }\end{array}$ & $31 / \mathrm{F}$ & $\begin{array}{l}\text { Simple and complex partial and grand } \\
\text { mal seizure ( } 2 \text { years) }\end{array}$ & SR & No & $\begin{array}{l}12 \text { months/no recurrence/epilepsy } \\
\text { remaining even with AED }\end{array}$ & (6) \\
\hline 7 & 2013 & Rt. temporal, uncus & $41 / \mathrm{M}$ & $\begin{array}{l}\text { Confusion after motor vehicle acci- } \\
\text { dent ( } 1 \text { episode) }\end{array}$ & $\mathrm{TR}$ & No & 60 months/no recurrence & (6) \\
\hline 8 & 2013 & Rt. temporal & $63 / \mathrm{F}$ & Lt. numbness and tingling ( 1 year) & TR & No & 36 months/no recurrence & (6) \\
\hline 9 & 2013 & Lt. temporal & $64 / \mathrm{M}$ & Staring and mumbling ( 1 episode) & Biopsy & No & No follow-up & (6) \\
\hline 10 & 2013 & Lt. frontal & $52 / \mathrm{F}$ & Episodic vertigo (2 years) & TR & No & No follow-up & (6) \\
\hline 11 & 2014 & Lt. frontal & $34 / \mathrm{F}$ & $\begin{array}{l}\text { Intractable epilepsy（26 years since } \\
\text { age } 8)\end{array}$ & $\mathrm{TR}$ & No & $\begin{array}{l}26 \text { months/no recurrence/seizures } \\
\text { decreased by } 50 \% \text { post-operation }\end{array}$ & $(2)$ \\
\hline 12 & 2014 & Lt. temporal & $71 / \mathrm{F}$ & $\begin{array}{l}\text { None (MND : dysarthria and increa- } \\
\text { sed difficulty with swallowing) }\end{array}$ & $\begin{array}{l}\text { Postmortem } \\
\text { diagnosis }\end{array}$ & No & 22 months/no regrowth & (2) \\
\hline 13 & 2015 & Lt. parietal & $37 / \mathrm{M}$ & Epileptic seizure with speech arrest & TR & No & $\begin{array}{l}60 \text { months/no recurrence/no epilepsy } \\
\text { post-operation }\end{array}$ & $(4)$ \\
\hline 14 & 2015 & Lt. frontal & $22 / \mathrm{F}$ & Continuous headache (2 weeks) & SR & No & $\begin{array}{l}6 \text { months/no recurrence/the patient } \\
\text { remained stable without further deterio- } \\
\text { ration of her clinical symptoms }\end{array}$ & $(7)$ \\
\hline 15 & 2016 & $\begin{array}{l}\text { Rt. temporal, hippocampus, } \\
\text { amigdala, uncus }\end{array}$ & $41 / \mathrm{M}$ & $\begin{array}{l}\text { Complex partial seizure after motor } \\
\text { vehicle accident ( } 22 \text { years) }\end{array}$ & SR & No & No follow-up & $(12)$ \\
\hline 16 & 2017 & Rt. temporal & $29 / \mathrm{M}$ & Complex partial seizure/headache & Biopsy & No & No follow-up & $(3)$ \\
\hline 17 & 2017 & $\begin{array}{l}\text { Lt. temporal, hippocampus, } \\
\text { amigdala, and para-hippocam- } \\
\text { pal gyrus }\end{array}$ & $59 / \mathrm{F}$ & $\begin{array}{l}\text { Partial seizures and generalized sei- } \\
\text { zure (onset } 39 \text { years old)/depression }\end{array}$ & UN & UN & $\begin{array}{l}108 \text { months/no recurrence/continued } \\
\text { seizures/declining verbal memory post- } \\
\text { operation }\end{array}$ & $(11)$ \\
\hline 18 & 2017 & $\begin{array}{l}\text { Rt. temporal, hippocampus, } \\
\text { amigdala, and para-hippocam- } \\
\text { pal gyrus }\end{array}$ & $32 / \mathrm{F}$ & $\begin{array}{l}\text { Impaired nonverbal learning/ } \\
\text { migraine/epilepsy many years }\end{array}$ & UN & UN & 72 months/no recurrence/seizure-free & $(11)$ \\
\hline 19 & 2017 & Lt. amigdala and hippocampus & $27 / \mathrm{F}$ & $\begin{array}{l}\text { Partial seizures and generalized sei- } \\
\text { zure (onset } 10 \text { years old) }\end{array}$ & UN & UN & $\begin{array}{l}168 \text { months/no recurrence/seizure-free/ } \\
\text { psychosis following temporal lobectomy }\end{array}$ & $(11)$ \\
\hline 20 & 2017 & Rt. occipital lobe & $62 / \mathrm{M}$ & Cause of death mesothelioma & $\begin{array}{l}\text { Postmortem } \\
\text { diagnosis }\end{array}$ & UN & No follow-up & $(11)$ \\
\hline 21 & 2017 & $\begin{array}{l}\text { Rt. posterior parietal-tempo- } \\
\text { ral lobe }\end{array}$ & $67 / \mathrm{F}$ & \begin{tabular}{|l|}
$\begin{array}{l}\text { Visual symptoms/partial seizures } \\
\text { (onset } 65 \text { years old) }\end{array}$ \\
\end{tabular} & Unknown & UN & $\begin{array}{l}24 \text { months/lesion stable/no neurological } \\
\text { deficit/seizure free }\end{array}$ & (11) \\
\hline 22 & 2017 & Lt. temporal & $48 / \mathrm{F}$ & $\begin{array}{l}\text { Partial seizures and generalized sei- } \\
\text { zure (onset } 47 \text { years old) }\end{array}$ & SR & UN & 24 months/no regrowth/seizure-free & $(11)$ \\
\hline 23 & 2017 & Lt. temporal & $6 / \mathrm{M}$ & Epilepsy & SR & UN & 17 months/no regrowth/seizure-free & $(11)$ \\
\hline 24 & 2017 & $\begin{array}{l}\text { Rt. temporal, hippocampus, } \\
\text { para-hippocampal gyrus, fusi- } \\
\text { form gyrus and hippocampus }\end{array}$ & $54 / \mathrm{M}$ & $\begin{array}{l}\text { Partial seizures and generalized sei- } \\
\text { zure (onset } 21 \text { years old) }\end{array}$ & UN & UN & $\begin{array}{l}10 \text { months/no regrowth/seizure-free/ } \\
\text { post operative facial weakness }\end{array}$ & $(11)$ \\
\hline 25 & 2017 & Rt. temporal & $41 / \mathrm{F}$ & Epilepsy & SR & UN & No regrowth & $(11)$ \\
\hline 26 & 2017 & $\begin{array}{l}\text { (Left or right is unknown) } \\
\text { Temporal }\end{array}$ & $55 / \mathrm{M}$ & Epilepsy & UN & UN & UN & $(11)$ \\
\hline 27 & 2017 & Rt. temporal & $52 / \mathrm{M}$ & Absence seizures (2 years) & SR & $\begin{array}{l}3 \text { sessions } \\
\text { of radiation } \\
\text { therapy }\end{array}$ & $\begin{array}{l}12 \text { months/no regrowth/asymptomatic/ } \\
\text { seizure-free }\end{array}$ & (5) \\
\hline 28 & 2018 & Rt. temporal & $54 / \mathrm{F}$ & UN & UN & UN & UN & (9) \\
\hline 29 & 2018 & Lt. temporal & $11 / \mathrm{F}$ & UN & UN & UN & UN & (9) \\
\hline 30 & 2018 & Rt. temporal & $19 / \mathrm{F}$ & UN & UN & UN & UN & (9) \\
\hline 31 & 2018 & Rt. temporal & $12 / \mathrm{M}$ & UN & UN & UN & UN & (9) \\
\hline 32 & 2018 & Lt. frontal & $60 / \mathrm{M}$ & No complaint & TR & No & 16 months/no recurrence & $(10)$ \\
\hline
\end{tabular}

SR : subtotal resection, TR : total resection, AED : antiepileptic drug, MND : motor neuron disease, UN : unknown 
んかん発症病変で皮質深層から皮質下白質にかけて，空 胞化異型神経細胞から構成される境界明瞭な多結節病変 である場合，MVNT を鑑別に挙げる必要がある。

\section{結 語}

MVNT の本来の定義は病理組織学的な多結節性で あったが，MRI 上も約半数に多結節性の病変を示す.

MAP kinase pathway の遺伝子変異も報告されている が，MVNTが腫瘍なのか形成異常なのかの結論には至っ ていない.

画像による診断後, 手術なしで経過観察しても，ほと んどの症例で増大を認めないことが報告されているが, MRI だけでは確定診断をつけることができない.MVNT の性質をより明らかにするためにも，MVNTが疑わ机る 場合には，他のグリオーマと鑑別することはできないの で，切除術または生検術を検討すべきである，病理組織 学的診断がついた場合には後療法なしで定期的な経過観 察をしてもよいと考えられる。

本論文に関して開示すべきCOI はありません。

\section{文 献}

1) Alsufayan R, Alcaide-Leon P, de Tilly LN, Mandell DM, Krings $T$ : Natural history of lesions with the MR imaging appearance of multinodular and vacuolating neuronal tumor. Neuroradiology $\quad \mathbf{5 9}:$ 873-883, 2017.

2) Bodi I, Curran O, Selway R, Elwes R, Burrone J, Laxton R, Al-Sarraj S, Honavar M: Two cases of multinodular and vacuolating neuronal tumour. Acta Neuropathol Commun $2: 7,2014$.

3) Cathcart SJ, Klug JR, Helvey JT, L White M, Gard AP, McComb RD : Multinodular and vacuolating neuronal tumor : A rare seizure-associated entity. Am J Surg Pathol $41:$ 1005-1010, 2017.
4) Fukushima S, Yoshida A, Narita Y, Arita H, Ohno M, Miyakita Y, Ichimura K, Shibui S : Multinodular and vacuolating neuronal tumor of the cerebrum. Brain Tumor Pathol 32: 131-136, 2015.

5) Gonzalez-Quarante LH, Ruiz-Juretschke F, Sola Vendrell E Gil de Sagredo Del Corral OL, Agarwal V, Garcia-Leal R: Multinodular and vacuolating neuronal tumor of the cerebrum. A rare entity. New case and review of the literature. Neurocirugia (Astur) 29: 44-55, 2018.

6) Huse JT, Edgar M, Halliday J, Mikolaenko I, Lavi E, Rosenblum MK : Multinodular and vacuolating neuronal tumors of the cerebrum: 10 cases of a distinctive seizure-associated lesion. Brain Pathol 23: 515-524, 2013.

7) Nagaishi M, Yokoo H, Nobusawa S, Fujii Y, Sugiura Y, Suzuki R, Tanaka Y, Suzuki K, Hyodo A : Localized overexpression of alpha-internexin within nodules in multinodular and vacuolating neuronal tumors. Neuropathology $35: 561-568$, 2015 .

8) Nunes RH, Hsu CC, da Rocha AJ, do Amaral LLF, Godoy LFS, Watkins TW, Marussi VH, Warmuth-Metz M, Alves HC, Goncalves FG, Kleinschmidt-DeMasters BK, Osborn AG : Multinodular and Vacuolating Neuronal Tumor of the Cerebrum : A new "Leave Me Alone" lesion with a characteristic imaging pattern. AJNR Am J Neuroradiol 38: 1899-1904, 2017.

9) Pekmezci M, Stevers M, Phillips JJ, Van Ziffle J, Bastian BC, Tsankova NM, Kleinschmidt-DeMasters BK, Rosenblum MK, Tihan T, Perry A, Solomon DA : Multinodular and vacuolating neuronal tumor of the cerebrum is a clonal neoplasm defined by genetic alterations that activate the MAP kinase signaling pathway. Acta Neuropathol 135 : 485-488, 2018.

10) Shitara S, Tokime T, Akiyama $Y$ : Multinodular and vacuolating neuronal tumor: A case report and literature review. Surg Neurol Int 9: 63, 2018.

11) Thom M, Liu J, Bongaarts A, Reinten RJ, Paradiso B, Jäger HR, Reeves C, Somani A, An S, Marsdon D, McEvoy A, Miserocchi A, Thorne L, Newman F, Bucur S, Honavar M, Jacques T, Aronica E : Multinodular and vacuolating neuronal tumors in epilepsy : dysplasia or neoplasia? Brain Pathol 28: 155-171, 2018.

12) Yamaguchi M, Komori $T$, Nakata $Y$, Yagishita A, Morino M, Isozaki $\mathrm{E}:$ Multinodular and vacuolating neuronal tumor affecting amygdala and hippocampus: A quasi-tumor? Pathol Int 66: 34-41, 2016. 
要旨

Multinodular and vacuolating neuronal tumor of the cerebrum の長期経過と文献的考察

$\begin{array}{lllllll}\text { 山澤恵理香 } & \text { 大野 } & \text { 誠 } & \text { 里見 介史 } & \text { 吉田 } & \text { 朗彦 } & \text { 宮北 康二 } \\ \text { 高橋 } & \text { 雅道 } & \text { 浅野目 } & \text { 卓 } & \text { 里見奈都子 } & \text { 成田 善孝 } & \end{array}$

Multinodular and vacuolating neuronal tumor of the cerebrum（MVNT）は比較的新しい疾患概念の ため, 長期観察された報告は少ない. 今回われわれは再発なく 5 年経過した自験例と, これまでに報 告された 31 例を対比しながら, MVNT の画像所見・治療経過をまとめた. これまでのところ年齢中 央值は 41 歳であり, 男女差はない. 病理組織のみでなく画像上も結節を認めるものが約半数存在し た. MVNTの症候性てんかんは手術により改善することが多い. これまでのところ MVNT の悪性転化 は報告されておらず, MVNT の予後は良好である.

脳外誌 $28 ： 27-32,2019$

\section{Editorial Comment}

\section{Multinodular and vacuolating neuronal tumor of the cerebrum $の$ 診断と治療適応}

熊本大学大学院生命科学研究部脳神経外科学分野 武笠晃丈

MVNT は, 著者らが述べているように, 2013 年に 提唱された新しい疾患概念であり，それ以降に確定 診断された症例の報告が 36 例しかないまれな疾患 である。側頭葉をはじめとした成人大脳半球に MRI で皮質から皮質下白質にかけての T2, FLAIR 高信 号域を認め，造影されることもまれなことから， low-grade glioma, ganglioglioma/gangliocytoma, dysembryoplastic neuroepithelial tumors, focal cortical dysplasia などが主な鑑別疾患になると思われる，著 者らは結語において,「MVNTが疑わ机る場合には, 他のグリオーマと鑑別することはできないので，切 除術または生検術を検討すべきである」と述べてい るが，これについては意見が分かれるところと思わ れる。なぜなら，考察に述べられているように，多 結節性の画像上の特徴などから MVNT と判断して,
経過観察のみを行った症例のほとんどにおいて腫瘍 の増大を認めておらず，腫瘍制御を目的とした摘出 の意義は乏しいと思われるからである。そこで難治 性のてんかん制御を目的とした場合を除くと, eloquent area に存在する場合などは特に, 摘出術や生 検術施行の判断は, 慎重に行う必要があるのではな いか. たとえば本症例では methionine-PET にて取 り込み増加を認めなかったというょうな diffuse astrocytoma や oligodendroglioma では比較的まれな 所見を呈しているが，このような補助画像診断も手 術適応判断の参考になる可能性はある. 現在 artificial intelligence を用いるなどした医用画像解析技術 のめざましい発展がみられているが, このような非 侵襲的な診断技術により, 不要な手術は極力回避で きるようになることを期待したい. 